\title{
Modified proverbs in al-Mạ̣mūd's Novel Muftaraq al-Mațar (The Parting of the Rain)
}

\author{
Huwaida Issa \\ Department of Arabic, Islamic and Middle Eastern Studies \\ University of Leeds, United Kingdom
}

\begin{abstract}
This paper, which develops ideas in my Ph.D. thesis (Issa, 2014), identifies a number of modified proverbs in a modern Arabic novel, Muftaraq al-Mațar, by the Syrian novelist Yūsuf al-Mahmūd. The study delves into how different scholars define modified proverbs (also sometimes referred to as deformed proverbs or anti-proverbs). The researcher will study a sample of adapted proverbs, regarding their new representation, and the effect of formal changes on their meaning, especially, when compared with their original structure. The study focuses on how the use of proverbs in narrative helps to flesh out the material and cultural life of $20^{\text {th }}$ century Syria. This is done mostly by re-contextualizing the adapted proverbs. In so doing, the paper also discusses the different techniques of modification identified by various researchers. Then the focus moves on Alan Partington's (1998, pp.126-8) four techniques for modifying phrases: substitution, insertion, abbreviation, and rephrasing. This is followed by an examination of sixteen modified proverbs, which are classified into four groups, each one representing the implementation of one of Partington's four techniques. Finally, the study examines the semantic effect of applying these techniques.
\end{abstract}

Key words: modified, proverbs, semantics, Syrian, technique

Cites as: Issa, H. (2019). Modified proverbs in al-Mạ̣mūd's Novel Muftaraq al-Mațar (The Parting of the Rain).Arab World English Journal for Translation \& Literary Studies, 3 (1) 257 275. DOI: http://dx.doi.org/10.24093/awejtls/vol3no1.20 